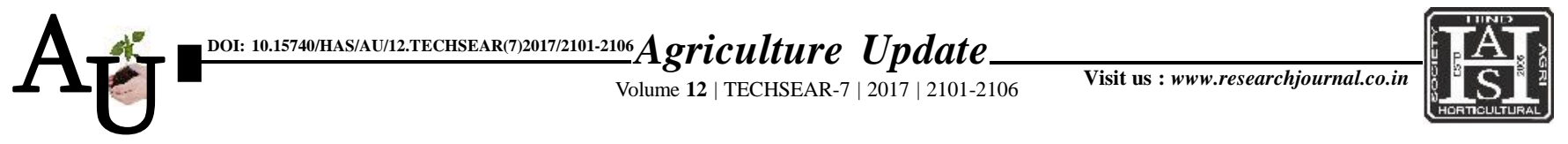

A REVIEW:

\title{
Full length review paper on cropping systems for sustainable vegetable production
}

\author{
G. RISHITHA, K. USHA KUMARI AND A. RESHMA
}

Article Chronicle:

Received :

19.07.2017;

Accepted :

03.08.2017

KEY WoRds :

Vegetables, Cropping systems, Multiple cropping
SUMMARY : India grows the largest number of vegetables in the world. Varied agro climatic conditions in India make it feasible to grow several vegetables round the year. As many as 61 annuals and 4 perennials are grown in India.Being short duration crops, vegetables are more susceptible to extremities in environment. And vegetable production is also not consistent due to weather extremities and diminishing natural resources. In countries like India it is a serious problem in view of large population depending on agriculture, excessive pressure on natural resources and poor cropping mechanisms. Malnutrition in children in India is also increasing alarmingly. Vegetables play an important role in achieving the nutritional security as they encounter the malnutrition problems in India and also serve as a source of income for the small and marginal farmers. The major objectives of reducing malnutrition and alleviating poverty indeveloping countries through improvedand consumption of safe vegetables that involves adaptation of current vegetable cropping systems like, multiple cropping, mixed farming, intercropping, and relay cropping systems. Integration of crop production, different farming systems with suitable soil and water conservation measures lead to sustainable production increase in income levels and towards better livelihoods. Major emphasis should be given on development of diverse technologies for optimization of farm resources, increased economic return and improved sustainability.

How to cite this article : Rishitha, G., Kumari, K. Usha and Reshma, A. (2017). Full length review paper on cropping systems for sustainable vegetable production. Agric. Update, 12(TECHSEAR-7) : 2101-2106; DOI: 10.15740/HAS/AU/12.TECHSEAR(7)2017/2101-2106.
Author for correspondence :

\section{G. RISHITHA}

College of Horticulture (Dr. Y.S.R. Horticultural University),

VENKATRAMANNAGUDEM (A.P.) INDIA

See end of the article for authors' affiliations 